\title{
A CONCEPTUAL FRAMEWORK FOR FORMALIZATION OF NATIONAL INNOVATION SYSTEMS
}

Wojciech NASIEROWSKI

\author{
Faculty of Business Administration \\ University of New Brunswick \\ Fredericton, NB E3B 5A3 Canada \\ e-mail nasierow@unb.ca
}

\begin{abstract}
The concept of National Innovation System (NIS) is explored from the perspective of its propensity for formalization. It is observed that there are problems with formalization (measurement) of NIS and consequently, deficiency in assessment of efficiency of pro-innovative ventures. Based on an overview of the literature, subsystems of NIS are identified and the leading topics within these subsystems are presented. Results of this study are believed to create the platform for formalization of NIS.
\end{abstract}

Key Words: National Innovation System, formalization, measurement, efficiency

\section{1}

\section{Introduction}

An increase in the level of innovativeness and enhancement of benefits from this activity are important ingredients in fostering economic activity and boosting competitive advantage. Innovation augments productivity, and thus contributes to the increase of GDP and wealth of the citizens (e.g. [28, 56]). The ability of governments, businesses and individuals to identify, respond to, and especially to introduce progressive change is the bedrock of competitive ability (e.g. [32, 9, 38, 52, 54, 16]). The more practitioners' perspective, taken at a micro-economic level, underlines continuous improvement in technology and business processes as vital to economic prosperity, thereby providing a strong incentive to invest in innovation [13, pp.133-140].

It should be noted though that innovation can be interpreted in different ways (e.g., [19, 50, 39, 41, 42, 44]). Further difficulties lie awaiting the researchers when they try to isolate means to stimulate creativity, as well as enhance innovativeness and entrepreneurship, along with attempting to improve economic performance of firms. And as if this is not enough, differences regarding interpretations are further amplified when micro and macro-economic perspectives are taken into account [45].

Innovativeness is not a new concept, yet issues of innovativeness are gaining more and more recognition. At the macro-economic level, innovation related efforts can be conceptualized within the concept of National Innovation Systems (NIS). There is no single definition of NIS [47] ${ }^{1}$. Yet, NIS can be defined as "a network of agents and set policies and institutions that affect the introduction of technology that is new to economy" [11, p. 541].

Lundval [29] identifies two schools of thoughts in the literature about NIS. The first, prevalent mostly in the USA, tends to define innovation in a narrow sense by focusing on science and technology policy, and mostly analyzes the systemic relationships between R\&Defforts in firms and organizations. The other school of thought looks at innovation in a broader sense and defines innovation as a continuous cumulative process involving not only radical and incremental innovation, but also the diffusion, absorption and use of innovation, besides science.

Since its emergence as a topic in management literature in the late 1980s, the concept of NIS has undergone significant changes, and has been "further elabo-

\footnotetext{
1 .. the network of institutions in the public and private sectors whose activities and interactions initiate, import, modify and diffuse new technologies. Freeman [20] claims: .... the elements and relationships which interact in the production, diffusion and use of new, and economically useful, knowledge ... and are either located within or rooted inside the borders of a nation state. For Lundvall [29];... a set of institutions whose interactions determine the innovative performance ... of national firms. For Nelson [46]; .... the national institutions, their incentive structures and their competencies, that determine the rate and direction of technological learning (or the volume and composition of change generating activities) in a country $[51] ; \ldots$. that set of distinct institutions which jointly and individualy contribute to the development and diffusion of new technolgies and which provides the framework within which governments form and implement policies to influence the innovation process. As such it is a system of interconnected institutions to create, store and transfer the knowledge, skills and artifacts which define new technologies [33].
} 
rated and theoretically underpinned in the early 1990s" [8, p. 5]. At the outset NIS served to define the key players related to innovation process and the scope of their activities. Works by Nelson [46], Lundval [30], Dosi, et al. [12] and Freeman [21] have not used a standardized structure of presentation of NIS, and have dealt with many countries independently, without an attempt to make cross-country comparisons. Key characteristic features of innovation processes and items that impact upon these characteristics have been determined. One of the lines of thinking about NIS has been directed towards the exploration of efficiency of NIS using parametric concepts. It is quite probable that if there are more Inputs there will be more Outputs, and therefore those who invest heavily may be considered more innovative. However, not only is the level of investment the key to success: efficiency of turning Inputs into Outputs also count. Several studies on the efficiency of organizations use the "best practice frontier" concept: the distance from such a frontier represents inefficiency -- the inability to produce maximum output from given inputs. Parametric approaches (e.g., regression methods) are used to estimate parameters of technical efficiency. However, many elements, such as multicollinearity, measurement error, and omitted variables, can weaken the precision of these parameter estimates [10]. Consequently, it may be more appropriate to depart from a cursory examination of a ratio of Inputs to Outputs (e.g., [15, 55]), and examine "best practice frontiers" using the nonparametric DEA. This means that the measure of technical efficiency (the Farrell Input Saving Measure of Technical Efficiency) is examined as the greatest proportion of inputs which can be reduced and still produce the same output [17], [18]. Several papers have reported results related to the use of this approach (e.g., [35, 43, 36, 38, 23]). According to Balazat and Hanusch [7, pp. 202-203] this approach can be regarded a new line of investigation of NIS that originated with works of Nasierowski and Arcelus a decade ago.

NIS can also be regarded as a subsystem of the national economy where a variety of agencies cooperate, and impact one upon another when carrying innovative projects. Whereas descriptions of NIS are easily available, there is no uniformly accepted idea of how to isolate its subsystems. The questions of formalization of NIS and its subsystems, and interrelationships among these subsystems remains unan- swered. These elements cannot be formalized and quantitatively examined. The same is true when the impact of the context of the operation upon the design of NIS is analyzed. The elements in thematic areas overlap, making reports on NIS, at times, redundant in terms of information content. Conclusions from such studies are difficult to quantify, as it is difficult to identify which solutions are correct, efficient and effective. All in all, the concept of NIS, albeit intellectually stimulating, remains as an abstract one and difficult to be interpreted from the perspective of daily operational activities. Thus, the objectives of this study is to explore the ability to "formalize ${ }^{2}$, the selected aspects of NIS.

In this paper (i) an overview of the concepts with regard to formalizing NIS will be presented, followed by (ii) a specification of NIS subsystems and their key discussion topics, and (iii) a suggested agenda for further studies.

\section{Formalization of NIS: Current stock of experience}

A model for investigation of NIS, in a more formalized manner, has been introduced by OECD [47], $[48]^{3}$, and thereafter by Arundel and Hollanders [3, pp. $\left.10-25^{4}\right]$, Lalkaka $\left[25^{5}\right)$, Liu and White $\left[27^{6}\right)$. Some leading policy themes have been identified, which can

\footnotetext{
${ }^{2}$ Identification of subsystems of NIS, leading topics (motives) within these subsystems, and interrelations among these topics, are an entry point to formalization (and measurement) of NIS.

${ }^{3}$ A new role of governments, building an innovation culture, enhancing technology diffusion, promoting networking and clustering, leveraging research and development, responding to globalization, learning from best practices (pp.63-68); and/or specialization in NIS, institutional profiles, linkages within and between NIS components (pp.21-48).

4 This model includes: promotion of Intellectual property Rights (IPR), commercialization of public research, R\&D and innovation, collaboration, finance, Human Resources (HR), targeted technologies, general policy.

${ }^{5}$ This model includes: S\&T Policy, innovation strategy, technical human resources, technical support services, mobilizing financial resources, international cooperation (pp.2-3), as well as setting priorities and allocating resources, develop strategies for scientific research and technology development in public, university and corporate laboratories, build the technical HR for a knowledge society, strengthen the technical support systems for quality, information flaws and the common concerns of alleviating poverty, preserving the environment and defending the nation, a look outwards towards attracting investment and alliances.

${ }^{6}$ This model includes: research, production, end-use (customers of the product or process outputs), linkage, education.
} 
be regarded as a starting point to identify subsystems of NIS, and consequently as an entry point in its formalization. Some ideas regarding NIS subsystems, or leading discussion topics in examination of NIC can also be derived from comprehensive reports e.g., EIS [15 - years $\left.2002-2009^{7}\right]$, trend Charts on innovation, OECD $\left[48 . \mathrm{pp} .10^{8}\right]$, as well as the Global Competitiveness Index $\left[22^{9}\right]$.

Based on an overview of the above sources the following subsystems in NIS can be proposed:

- governance of NIS (GNIS),

- commercialization of research results (CRR),

- human capital development (HCD),

- support to innovativeness (SIN).

These topics are consistent with the Lisbon Strategy [26] that is endorsed as a guide to scientific development of the European Union. These topics can be further explored within the subsystems and discussion topics presented in the next section.

\section{National Innovation Systems: Subsystems and discussion topics}

\subsection{Governance of NIS (GNIS)}

Productivity increases, largely resulting from innovations, which contribute to improved competitiveness and enhanced distinctive competencies of enterprises, are the key driving forces in boosting economic progress and standard of living. Consequently, governments structure systems that foster innovativeness. The key themes (motives) within governance of NIS include:

- assumptions regarding innovation underpinnings; these items evolve around key strategic objectives, such as improvement of productivity and educational levels, improvement of competitiveness, de-

\footnotetext{
${ }^{7}$ In EIS 2009 the following indicators have been used: human resources, finance and support, firm investments, linkages and entrepreneurship, throughputs, innovators, economic effects.

${ }^{8}$ This report has emphasized: stable macroeconomic environment, a supportive tax and regulatory environment, appropriate infrastructure and education and training policies, removal of barriers to innovation in the business sector and increase in synergies between public and private investment in innovation.

${ }^{9}$ The key groups of indicators used are: institutions and policies, human capacity, infrastructure, technological sophistication, business markets and capital, knowledge, competitiveness, and wealth.
}

fining areas of specialization and their coordination with the macro-economic agenda,

- institutions/agencies involved in innovations, their structure, relationships, and responsibilities: this set of topics discusses institutional arrangements behind pro-innovation activities; thus, governments set up institutions to deal with this issue, e.g., in the format of the Ministry of Economic Affairs, the Ministry of Education, Culture and Science, university systems, agencies, etc.; "Innovation performance depends not only on how specific actors perform, but on how they interact with one another as elements of an innovation system, at local, national, and international levels" [48, pp. 10],

- control mechanisms regarding efficiency of innovation systems, its agencies and policies that may improve innovativeness levels,

- promotion of innovation friendly environment, that deals with the atmosphere within which innovations evolve; this atmosphere can be impacted by governments through free flow of information, easy access to ICT, efficient protection of intellectual property rights (IPR) (patents, trade-marks, copy-rights, etc.), simplifications in conditions of running business, and anti-monopolistic regulations.

\subsection{Commercialization of research results (CRR)}

The commercialization of research results means taking innovations from paper to realty. Whether for improvement of economy, monetary, social, or environment benefits, commercialization involves putting innovations into actual use. Research into innovative products, services and ideas is abundant, but without their application and effective use, these ideas account for nothing. Karlsson [24, pp. 83-85] claims that the following are of key importance: availability of private capital, ownership of research results, entrepreneurial skills, small business involvement, governmental programs, and commercialization drive at universities.

The commercialization of research is paramount to the idea of NIS, and essential to any economy's ability to compete globally. 
The following key topics can be discussed within this subsystem:

- Collaboration (networking) between governmental institutions, research institutes and laboratories, universities and business (private sector and entrepreneurs), including issues of public vs private research. There are many players in a NIS, and unless they cooperate, no one wins. All the participants bring different assets to the table: governments - have capital; research institutions and universities - have knowledge; research - findings and people ready to work towards innovation; while businesses and entrepreneurs - have the ideas. Without the interaction and cooperation of all the involved parties, innovative ideas go nowhere. Whereas R\&D mainly means inventions, business R\&D means the ability to develop business practices that allow innovation to be more easily commercialized. Thus, the link between public and business types of involvement, and collaborative links between such institutions that deal with the flow of money should be explored.

- Encouraging technology and knowledge transfer to firms, and the development of innovation clusters. In order to see innovations become successful, businesses and entrepreneurs need access to information, technology, legal services, etc. As well, there is normally the need for the private capital to support innovative ventures, and the clarification of ownership rights (e.g., Baye-Doyle Act). Involvement of SME and development of entrepreneurial skills are desirable (e.g., [24, pp. 83-85]. This is critical for innovations to reach the application stage.

- Support to targeted technologies and specialization patterns: this sub-topic emphasizes the need to focus strengths on what a country does best, or what it believes will bring successes. Similarly, some claim that investment in lagging areas is likely to be more efficient [53]. Innovation should be efficient and effective, and for a country with an existing competitive edge, applying innovations in areas that are weak vs. strong could mean the difference between a lagging economy and a real competitive advantage.

\subsection{Human capital development (HCD)}

Human Resources within the NIS context may be defined as individuals and their groups, mainly in the work-force, who have direct or indirect impact upon innovativeness. These individuals are not limited to scientists, engineers, and technologists, but also include, administrators and support staff, who facilitate innovation process. Issues of HR within NIS context also include regulations and policies that impact upon attitudes, knowledge and skills of people, and their availability for economic activities:

- investment in the quality of human resources for innovation: this sub-topic is crucial because without quality human resources it is not possible to move forward with innovations; to this end it is important to identify means used to enhance capabilities of people,

- efforts to increase the number of people in science, engineering and technology (SET) areas: SET is pivotal to innovations, and there is an anticipated shortage of people entering these fields; within this sub-section aspects related to the number of graduates entering SET careers, expenditures on education, education standards (as measured by achievements in mathematics, for example) can be explored from the viewpoint of NIS policies and activities,

- job creation, retention, and reducing unemployment: this topic explores actions taken by governments and companies that allow efficient use of available human capital,

- means to improve labor productivity issues that deal with the activities which may contribute to the increase of labor productivity, which is normally positively correlated with improvement of quality of outputs, and enhancement of innovativeness.

\subsection{Support to Innovativeness (SIN)}

Financing innovation is about putting in place programs, funds, and tools that allow the stimulation of innovation. This is done in many ways: direct financing, support of governmental research institutes, grants, access to research infrastructure, and institutionalizing policies that allow innovation to flourish. The following topics are here frequently discussed:

- direct support to innovativeness, such as: grants, loans, direct support to finance $R \& D$ and no- $R \& D$ innovations, tax reductions for pro-innovative projects, subsidies for buildings/infrastructure for innovation activities, subsidies for acquiring machinery, equipment, software, funding $R \& D$, tax 
reductions for innovation expenditures other than R\&D [3, 4, pp. 27],

- indirect support to innovativeness in the form of: trade fairs, trade missions, information on market needs, training, seminars, legislative arrangements, support to the development of research infrastructure (including ICT), innovation and science parks, technology incubators, information and research infrastructure, creating motivation and incentives for businesses, supply of $\mathrm{PhDs}$ in SET, support to new-technology-based-firms, regulations regarding ownership of proprietary rights, simplification of access to private (venture) capital, etc.; these items are crucial, because without ideas, money and innovations the economy cannot become competitive,

- accounting and legal practices that stimulate/hamper innovativeness; to be noted beyond an inflow of funds that support innovative activities, such activities can be stimulated (or confined) by non-financial arrangements; this deal for example with accounting rules that may classify an activity as R\&D.

\section{Concluding remarks and suggestions for future}

\section{Defining NIS}

As discussed in this paper, there seems to be no consensus among experts as to what exactly NIS means. Researchers should attempt to arrive at an acceptable definition of NIS that would allow the measurement of NIS related variables. Results of literature analysis related to innovations persistently suggest that even though discussion is about similar phenomena, there is a gap between assessment of innovativeness from the viewpoint of macro-economic indicators (as expressed, for example, by the European Innovation Scoreboard) [55], with perceptions of entrepreneurs that resort themselves to a micro-economic perspective [13]. Concerns related to the differences may be summarized as in Table 1.

Composite indexes of innovativeness and NIS subsystems

Once semantic dilemmas associated with innovations are resolved, questions of measurement of NIS can be explored more in detail. Questions in this area deal with the identification of indicators that indeed are oriented on innovativeness (not necessarily inventive- ness), determinants of innovativeness, and thus can serve as a policy setting aid. There is a need to identify composite indexes that reflect the level of innovativeness, and as well can be used to control the level of achievement of objectives related to technological progress. Such an index should be user friendly, universal, rooted in easily available (and quantifiable) data series, prone to be used as policy making guidance and comprehensive composite indexes of the level of innovativeness. A validation of such an index can be done through comparison of its rankings of countries to those produced by other composite indexes.

To be noted, there is a host of indexes that pretend to 'measure' selected aspects of NIS, as well as a variety of composite indexes that measure/rank countries with respect to innovativeness levels (or can be considered as a proxy of innovativeness) [42, 1, 2 and 34].

Table 1. Differences between 'macro' and 'micro' perspectives to innovativeness

(source: [41, 44, 45])

\begin{tabular}{|l|l|}
\hline \multicolumn{1}{|c|}{ MACRO } & \multicolumn{1}{c|}{\begin{tabular}{c}
\multicolumn{1}{c|}{ MICRO } \\
PERSPECTIVE
\end{tabular}} \\
\hline inventions (exploration) & $\begin{array}{l}\text { innovations (exploita- } \\
\text { tion) [31] }\end{array}$ \\
\hline $\begin{array}{l}\text { composite indexes } \\
\text { fragmented questionnaire } \\
\text { studies with little chance } \\
\text { to find an unifying pat- } \\
\text { tern }\end{array}$ \\
\hline $\begin{array}{l}\text { government, } \\
\text { theory efficiency }\end{array}$ & $\begin{array}{l}\text { SME, practice, } \\
\text { effectiveness }\end{array}$ \\
\hline $\begin{array}{l}\text { correctness } \\
\text { (political, legal) }\end{array}$ & $\begin{array}{l}\text { profit, risk reduction, } \\
\text { competitive position }\end{array}$ \\
\hline $\begin{array}{l}\text { laboratories, } \\
\text { research centers }\end{array}$ & $\begin{array}{l}\text { technology incubators, } \\
\text { daily practice }\end{array}$ \\
\hline $\begin{array}{l}\text { grants, } \\
\text { formal contracts }\end{array}$ & loans \\
\hline formal training programs & $\begin{array}{l}\text { informal } \\
\text { business meetings }\end{array}$ \\
\hline $\begin{array}{l}\text { setting rules and } \\
\text { standards }\end{array}$ & adopting to conditions \\
\hline $\begin{array}{l}\text { WHAT DO } \\
\text { COMPANIES WANT? }\end{array}$ & $\begin{array}{l}\text { WHAT CAN GOV- } \\
\text { ERNMENTS OFFER? }\end{array}$ \\
\hline
\end{tabular}


To be noted, however, definitions do not bring clarity, formalization, and later on measurement of aspects of these constructs is hard to accomplish, and concurrently, it is unpractical to the independent, isolated researcher to propose his own interpretations. It may be suggested to draw from the stock of existing knowledge, select one set of solutions, and then follow them consistently through the study.

\section{Efficiency}

Once means to quantify aspects of NIS are determined, concerns of the evaluation of efficiency can be addressed. Identification of efficiency of innovation policies used in different countries (here: efficiency of turning inputs into outputs) can be achieved, for example, using "Farrell Input-Saving Measure of Technical Efficiency" and the DEA method. Based on an assessment of efficiency, the key points for policies oriented on enhancing innovativeness can be established. These key points, along with the results of analysis of detailed innovation policies, may lead to the identification of "best practice frontier innovations" (BPFI) applicable to the specific context.

\section{Longitudinal studies}

Once the means to quantify aspects of NIS are determined, some stability while measuring innovativeness can be achieved. Then, longitudinal studies may be undertaken to cross-validate the assessment of accuracy of procedures and policies. It is important to remember, however, that some leading indexes of innovativeness change their selection of indicators. Thus, the research problem will also rest with the identification of results produced by adopted policies, irrespective of indicators used in the index. Certainly the problem of isolating results of these approaches from market forces, for example, will remain complex to be resolved. As well, it will be interesting to explain whether countries and companies are innovative because they are rich, or is it vice-versa, and countries and companies with wealth are, as a proverbial consequence, innovative?

\section{Agenda for future research}

The advancement in finding clarity in the above specified areas will have several managerial and scholarly implications. Despite growing integration through the European Union (EU), considerable differences do exist between European countries with respect innovation 'philosophy' and the role of governments in fostering a supportive environment.
The way $\mathrm{R} \& \mathrm{D}$ is allocated in different countries also sheds light on priorities of governments and may require different managerial approaches (note: the EIS, for example, takes an implicit assumption regarding uniformity of NIS policies). Future researchers of the topic should also look at emerging economic superpowers such as China and India - the concentration on diffusion of knowledge, instead of for knowledge creation, may be an idea to consider. Issues of NIS formalization (as presented in this paper) may serve as an outline for further studies, fragmented to distinct sub-systems and topics. However, exploration of these topics cumulatively may contribute to the clarification of issues if innovation principles, and the key role of NIS.

\section{$5 \quad$ References}

[1] Archibugi D., Denni M., Filippetti A. - The technological capabilities of nations: The state of the art. of synthetic indicators [in] Technological Forecasting and Social Change, Vol. 76, Issue 7, 2009, pp. 917-931.

[2] Archibugi D., Coco A. - A new indicator of technological capabilities for developed and developing countries ( $\mathrm{ArCo}$ ) [in] CEIS Tor Vergata Centre for International Studies on Economic Growth. Vol. 15, No. 44, 2004.

[3] Arundel A., Hollanders H. - Policy indicators and targets: Measuring the impact of innovation policies. European Commission 2005.

[4] Arundel A., Hollanders H. - 2006 Trend Chart Methodology Report: Searching the forest for the trees: Missing indicators of innovation. Maastricht Economic Research Institute on Innovation and Technology 2006.

[5] Arundel A., Bordoy C., Kanerva M. - Neglected innovators: How do innovative firms that do not perform R\&D innovate? Inno-Metrics thematic Paper, Merit 2008.

[6] Balzat M., Hanusch H. - Recent trends in the research on National Innovation Systems. Institut fur Volkswirtshaftslehre, Beitrag, No. 254, 2003.

[7] Balzat M., Hanusch H. - Recent trends in the research on National Innovation Systems [in] Journal of Evolutionary Economics. No.14, 2004, pp. 197-210.

[8] Balzat, M., Pyka, A. - Mapping national innovation systems in the OECD area [in] International 
Journal of Technology and Globalisation. Vol. 2, No. 1-2, 2006, pp. $158-176$.

[9] Blanke, J., Fiona P., Sala-i-Martin X. - The Growth Competitiveness Index: Analyzing Key Underpinnings of Economic Growth [in] Global Competitiveness Report of the World Economic Forum. Chapter 1.1, 2003.

[10] Chapple W., Lockett A., Siegel D., Wright M. Assessing the relative performance of U.K. university technology transfer offices: parametric and non-parametric evidence [in] Research Policy. Vol. 34 (3), 2005, pp. 369-384.

[11] Dahlman C.J. - Technology strategy in East Asian developing countries [in] Journal of Asian Economics. No. 5, 1994, pp. 541-572.

[12] Dosi G., Freeman C., Nelson R., Silverberg G., Soete L. - Technological Change and Economic theory. Pinter Publishers, London 1988.

[13] Drucker P. - Innovation and entrepreneurship: practice and principles. Harper \& Row, New York 1984.

[14] Edquist C. - Systems of Innovation: Technologies. Institutions, and Organizations, Pinter, London 1997.

[15] European Innovation Scoreboard. Inno-Metrix, 2005, 2006, 2007, 2008.

[16] Fagerberg J. - Technology and international differences in growth rate [in] Economics of Innovation and New Technology, Vol. 3, 1994, pp. 83-200.

[17] Färe R., Grosskopf S. - Reference guide to OnFront, Economic Measurement and Quality. Lund AB, Lund 1998.

[18] Färe R., Grosskopf S. - User's guide to OnFront. Economic Measurement, Quality and Lund AB, Lund 1998.

[19] Frascati Manual: The Measurement of Scientific and Technological Activities. OECD, Paris 2002.

[20] Freeman C. - Technology and Economic Performance: Lessons from Japan. Pinter, London 1987.

[21] Freeman, C. - The National System of Innovation in historical perspective [in] Cambridge Journal of Economics. Vol. 19, 1995, pp. 5-24.

[22] Global Innovation Index. Insead, The Business School for the World 2009.

[23] Hollanders H., Esser F.C. - Measuring innovation efficiency. ProInno Europe. InnoMetrics, 2007.
[24] Karlsson M. - Commercialization of Research Results in the United States: An overview of Federal and academic technology transfer. Swedish Institute for Growth policy Studies, 2004.

[25] Lalkaka R. - National Innovation Systems: Role of research organizations and enterprises. IV International Symposium on Environmental Biotechnology, Veracruz, Mexico 2002.

[26] Strategia Lizbońska: droga do sukcesu zjednoczonej Europy. Wyzwania członkowstwa. Urząd Komitetu Integracji Europejskiej, Ideapress, Gdańsk 2002.

[27] Liu X., White S. - Comparing innovation systems: A framework and application to China's transitional context [in] Research Policy. Vol. 30 (6), 2001, pp. 1091-1114.

[28] Lööf H. and Heshmati, A. - On the Relationship between Innovation and Economic Performance [in] Economics of Innovation and Technological Change. Vol. 15, 2006, pp. 317-344.

[29] Lundvall B. - National Innovation Systems Analytical concept and development tool [in] Industry and Innovation. No. 14 (1), 2007, pp. 95119.

[30] Lundvall B. (ed.) - National Systems of Innovation: Towards a Theory of Innovation and Interactive Learning. Pinter Publishers, London 1992.

[31] March J.G. - Exploration and exploitation in organizational learning [in] Organization Sciences. Vol. 2, No 1, 2000, pp. 71-87.

[32] McArthur J. W., Sachs J.D. - The Growth Competitiveness Index: Measuring Technological Advancement and the Stages of Development [in] Global Competitiveness Report 2001-2002. New York: Oxford University Press for the World Economic Forum, 2003.

[33] Metcalfe S. - The Economic Foundations of Technology Policy: Equilibrium and Evolutionary Perspectives [in] Handbook of the Economics of Innovation and Technological Change (Stoneman P.ed.). Blackwell Publishers, Oxford (UK) / Cambridge (US) 1995.

[34] Mirchandani D. - Economic and social indicators of global competitiveness: An analysis of country rankings. 8th International Eastern Academy of Management Conference, Prague 1999.

[35] Nasierowski W. - Zarzadzanie rozwojem techniki: Perspektywa krajowych systemów. EuroManagement, Poltext, Warszawa 1997. 
[36] Nasierowski W., Arcelus F. - Interrelationships among the elements of National Innovation Systems: A statistical evaluation [in] European Journal of Operations Research. Vol. 119, 1999, pp. 235-253.

[37] Nasierowski W., Arcelus F. - National technology policies and stability of NTS indexes. Atlantic Schools of Business Conference, Halifax, 1999.

[38] Nasierowski W., Arcelus F. - On the efficiency of national innovation systems [in] Socio Economic Planning Sciences. Vol. 37, 2003, pp. 215234.

[39] Nasierowski W. - Mierzenie innowacyjnosci MSP: dylematy badan i porównań międzynarodowych [w] Zarządzanie Organizacjami Gospodarczymi w Zmieniającym się Otoczeniu (Lewandowski J. ed.). Wydawnictwo Politechniki Łódzkiej 2004, pp. 175-183.

[40] Nasierowski, W. - Criteria for assessment - selection of innovative projects. Portland International Center for Management and Engineering and Technology '06 Conference, Istanbul 2006.

[41] Nasierowski W. - Mierniki i indeksy innowacyjności [in] Ekonomika i Organizacja Przedsiębiorstwa. No 2 (697), 2008, pp. 19-28.

[42] Nasierowski W. - Some observations regarding composite indexes of economic performance. North-East Decision Sciences Institute Conference, New York 2008.

[43] Nasierowski W. - Assessment of technical efficiency of NIS with the use of DEA. ICMIT-IEEE Conference, Bangkok 2008.

[44] Nasierowski W. - On the stability of countries' National Technology Systems [in] Recent Developments and Applications in Decision Making (Zanakis S.H., Doukidis G., Zopounidis C. ed.), Kluver Academic Publishrs, 2000.

[45] Nasierowski W. - Composite Indexes and Indicators of Innovativeness: Some Critical Commentsi [in] Innovation in Management: Cooperating Globally (Wankel Ch.ed). Poznan 2009, pp. 7488.

[46] Nelson R. (ed.) - National Innovation Systems. A Comparative Analysis. Oxford University Press, New York/Oxford 1993.

[47] OECD - National Innovation Systems. OECD Publications, Paris 1997.

[48] OECD - Managing National Innovation Systems. OECD, Paris 1999.

[49] Ohmae K. - The end of the nation state - how regions states harness the prosperity of the global economy. Free Press - McMillan, New York 1993.

[50] Oslo Manual - OECD proposed guidelines for collecting and interpreting technological innovation data. OECD/EuroStat, Paris (KBN 1999) 1999.

[51] Patel P., Pavitt K. - The Nature and Economic Importance of National Innovation Systems [in] STI Review. No. 14, OECD, Paris 1994.

[52] Porter M. - Competitive advantage of nations. Free Press, New York 1990.

[53] Rodriguez-Pose A. - Is R\&D investment in lagging areas of Europe worthwhile? Theory and empirical evidence [in] Regional Science, 2001, pp. 275-295.

[54] Rutten R., Boekema F. - Innovation, policy and economic growth: Theory and cases [in] European Planning Studies. Vol. 13, issue 8, 2005, pp. 1131-1136.

[55] Sajeva, M., Gatelli, D., Tarantola, S., Hollanders, H. - Methodology Report on the European Innovation Scoreboard 2005. European Commission, Enterprise Directorate-General 2005.

[56] Shariff N. - Emergence and development of the National Innovation System concept [in] Research Policy. Vol. 35, 2006, pp. 745-766. 